\title{
LINGUISTIC LANDSCAPES IN A WESTERN UKRAINIAN TOWN
}

\author{
KORNÉLIA HIRES-LÁSZLÓ
}

\begin{abstract}
In this paper I describe how we identified the language symbols used on street and road signs in Ukraine's westernmost town, Berehove. In linguistic landscape studies, multiethnicity is a significant aspect indeed. Insofar as numerous ethnic groups live in Berehove side by side, it seems plausible to analyze the linguistic landscape of this settlement. In this study, two analyses (involving linguistic landscape items collected in 2013 and 2017) are used to elucidate this settlement's linguistic landscape. I demonstrate the linguistic landscape collections using two methods of analysis (quantitative and qualitative), studied in a town characterized by its multilingual history. I also analyze ethnolinguistic vitality research in bilingual settings of various time lines. Furthermore, I introduce inscriptions and symbols collected at a street fair in relation to their language and its richness.
\end{abstract}

KEYWORDS: Transcarpathia, Berehove, linguistic landscape, multiethnicity

\section{INTRODUCTION}

Nowadays, linguistic landscape analyses are applied in many branches of science (Ben-Rafael 2010). The essence of the method is elucidating and accurately explaining the underlying motivation, ideology, and power struggles behind linguistics landscape items of various forms. Linguistic landscape research is predominantly used to analyze the multilingualism of multiethnic territories (Laihonen 2012, Csernicskó - Laihonen 2016, Landry - Bouris 1997, Scollon - Scollon 2003). It introduces the conditions for the coexistence of languages, their characteristics, the dominant position of some languages, their dissonance or harmonious coexistence, as well as the forms

1 Kornélia Hires-László is an adjunct and researcher at Ferenc Rákóczi II Transcarpathian Hungarian Institute, Hodinka Antal Linguistic Research Centre, Berehove, e-mail: hlkornelia@gmail.com. 
the minority and state languages appear in (Barni-Bagna 2015). We collected inscriptions in Ukraine's westernmost town of Berehove. Our analysis was undertaken on the basis of two previous articles in Hungarian (Hires-László 2018a, 2018b). The settlement is relevant for linguistic landscape analysis from three points of view.

First, numerous ethnic groups live in Berehove side by side; a significant feature in multiethnicity studies. The multiethnic character of the settlement has not formed over the past 10-20 years, but over a much more extended period (Csernicskó - Orosz 1999, Csernicskó - Máté 2017). Numerous ethnic groups live side by side, not only in the settlement under analysis; this characteristic is true of the whole region - Transcarpathia. The two dominant ethnic groups in the area and in the settlement include the Ukrainian ethnos belonging to the state-nation (some researchers question the inclusion of the Russian and Rusyn ethnic groups; however, we do not wish to take part in this debate here), as well as the Hungarians that have become a minority as a result of historical changes (Fedinec - Vehes 2010).

Second, Transcarpathian Hungarians are mostly concentrated in Berehove district, which is the reason why this town plays a significant role in the life of local Hungarians. Analysis of the linguistic landscape conducted in the settlement proves suitable for describing the minority Hungarians' fate, and illustrating their opportunities for language use as well as their language prestige. Shohamy $(2006,2015)$ shows how important the role of the linguistic landscape can be in the process of language choice. Language policy processes include the essence of the linguistic landscape. In its interpretation, the linguistic landscape reveals the ideologies that influence various language policy measures (such as laws and edicts) (Shohamy - Waksman 2009: 314). Language policy analyses related to the linguistic landscape, presuppose, first of all, an analysis of public places (Backhaus 2006, Laihonen 2012, Shohamy - Waksman 2009) that is capable of revealing the symbolic expansion of language. This expansion is mostly provided for and guaranteed by the legal opportunities awarded a language (see further information on the language policy opportunities in Ukraine in Csenicskó 2016). The use of the Hungarian language, as well as of national symbols in the settlement described herein, can nurture Transcarpathian Hungarians' linguistic self-confidence.

The third factor is a tendency that includes an economic process. On the basis of our present analysis, this is the most significant factor. Namely, the settlement has become a place favored- and visited by tourists over the last five to ten years. The evolution of this new economic sector has caused numerous changes in the town's life. Moreover, it has brought about changes in society and culture. Our next step is analyzing the influence of the spread of tourism on the town's 
former traditions, as well as studying the inscriptions in the town's public places and at street fairs. In other words, in the process of analyzing the linguistic landscape, we are searching for changes brought about by tourism by means of applying a qualitative research method.

Linguistic landscape analysis is based on two approaches: quantitative and qualitative (Shohamy - Ben-Rafael 2015). We use both methods in our study and compare linguistic landscape elements from two different times (2013 and 2017) based on the three features described above. Such a multifaceted linguistic landscape analysis at a local site can explain some social phenomena and processes. With the analysis hereby presented, we can increase the encounters of the disciplines often mentioned in linguistic landscape analysis, as well as combine the use of quantitative and qualitative methods. In addition, by presenting the linguistic landscape of a Ukrainian, Transcarpathian multiethnic town, we can shed some light on the image of the country and the region that has formed in the media, science and public life. In what follows, one can first read a current policy review. The circumstances of the photos collected for analysis are then discussed, and a deeper analysis is presented.

\section{POLITICAL EVENTS IN UKRAINE THAT ARE RELEVANT FOR OUR LINGUISTIC LANDSCAPE ANALYSIS}

The settlement under analysis is situated in Transcarpathia. This region is one of the 24 regions designated by Ukraine's former and official forms of state governance. Ukraine's territorial military unity has been fragmented by riots and military action that have been going on since 2014. This process started with peaceful demonstrations that resulted in a transition of power and were followed by street fights in Kiev. The demonstration preceding the riot was called Euromaidan in the vernacular or the Revolution of Dignity. The consequence of this revolution was Russia's annexation of the Crimean peninsula.

Furthermore, after the Russian military intervention into Eastern Ukraine, the regions of Donetsk and Lugansk proclaimed their autonomy (Lugansk and Donetsk People's Republic). "Ukraine became the object of suffering in a global geopolitical struggle" (Fedinec - Halász - Tóth 2016: 225). The Russian-speaking population of the eastern part of the country did not want to become victims of anti-Russian political arrangements, and as a result took up arms with annexation in mind (establishing the Donetsk People's Republic on 7 April, 2014 and the Lugansk People's Republic on 24 April of the same year). At this time a cold war started in the country and Kyiv launched an 
anti-terrorist military operation on the affected territories (commonly called "ATO"), strengthening of the army commenced (all former soldiers were mobilized), and the national guard was formed. To stop the war in the country's eastern part, European Union delegates attempted to enforce a ceasefire, although fighting of various intensity has continued (2017 autumn). Eventually, Ukraine signed an association and free-trade agreement with the EU on 27 June, 2014 (Fedinec - Halász - Tóth 2016:109-111; see further information on Ukraine's present situation and its relations with neighboring states in Fedinec - Csernicskó 2017a, 2017b). After the outbreak of the war, people's daily routines involved not only political and economic instability. Men, often married with children, often went abroad to escape joining the line infantry and the military draft. Soon they were followed by the rest of their families with the aim of family reunification. As a result of the 20132014 series of events, political and economic instability engulfed the whole country, including Transcarpathia. The situation of minorities became even more problematic after nationalist forces rose to power who wished to follow a nationalist Ukrainian state-building model. In this process, they aimed at assimilating the population with a Russian or dual identity by enforcing the use of the Ukrainian language and promoting Ukrainian national awareness. On 5 September, 2017, the second reading of the law on education was passed. The essence of this is that it obligates the use of the Ukrainian language in all public education institutions, but grants the use of minority languages in kindergartens and primary schools. This law aims at the assimilation of all the minorities in the country (similarly to the 2008 edict) (see continuously updated details about the law on education at the site http://hodinkaintezet. uz.ua/). In the spring of 2019 presidential elections were held in Ukraine. After the election, the whole country will look forward to experiencing the new president's promises of change (improvement of the Russian-Ukrainian relationship, support for minorities, the eradication of war, corruption, and the recovery of the economy).

\section{METHODOLOGICAL CONSIDERATIONS}

The method essentially comprises qualitative and quantitative elements, as well as their combination (Shohamy - Ben-Rafael 2015). In the process of quantitative analysis, collected illustrations are classified according to various points of view, and their proportion (per cent) or frequency distribution is revealed. For the qualitative analyses, the content and interpretations of readers/ viewers in terms of the placement of linguistic landscape items in public places 
are much more critical. In the case of content analysis, features characteristic of the direct social setting were interpreted together with appraisals of the languages' symbolic significance. We applied both methods in our analysis. On the one hand, we used quantitative methods to introduce the settlement's traditional multilingualism, while on the other we used qualitative methods to formulate in general the settlement's characteristic bilingualism, and to analyze the inscriptions collected at a street fair.

In relation to the quantitative analysis of the linguistic landscape, Ben-Rafael et al. (2006) elaborated a system of categories whose essence is the study and assessment of the language use of inscriptions in public places that takes into account language policy processes. The appearance of languages and their use in various locations may thereby be investigated: these are assessed not only on the basis of their symbolic meaning but also taking into account language rights and opportunities. In this case, it becomes essential whether inscriptions were initiated by an individual (bottom-up) or an administrative unit or organization (top-down) (Ben-Rafael et al. 2006).

The authors elucidate the fact that three critical factors are relevant in relation to the symbolic organization of public places:

- rational consideration, in essence, this deals with the level of signs at which they attract attention in terms of their practical function for public and clients: e.g. the attractiveness and expected influence of signs on recipients; - presentation of the self for the public: i.e. individual aspirations expressed in community identity markers using various patterns;

- power relations - here appear the social and political forces that determine the most important values (Ben-Rafael et al. 2006:7; 9-10).

The essence of the analysis, besides its implications for language policy, relates to the degree of formality of the inscriptions. Thus, the inscriptions in public places are assessed according to whether they were put up by private persons, official (state) organs, or civil organizations.

Table 1 Interpretation of signs registered in the linguistic landscape on the basis of official (top-down) and private (bottom-up) initiatives (Ben-Rafael et al. 2006:14)

\begin{tabular}{|c|c|}
\hline Top-down initiative & Bottom-up initiative \\
\hline $\begin{array}{l}\text { - public institutions: religious, governmental, } \\
\text { municipal-cultural, educational, and medical } \\
\text { - public signs of general interest } \\
\text { - public announcements } \\
\text { - street names }\end{array}$ & $\begin{array}{l}\text { - Shop signs: e.g. clothing-, food-, jewelry } \\
\text { shops } \\
\text { - Private business signs: offices, factories, } \\
\text { agencies } \\
\text { - Private announcements: 'wanted' ads, sales } \\
\text { or rentals of flats or cars. }\end{array}$ \\
\hline
\end{tabular}


The top-down signs were coded on the grounds of their belonging to local, cultural, social, educational, medical or legal institutions. Bottom-up signs were coded according to the following categories: professional (legal, medical, consulting), commercial (and later its branches, e.g. food, clothes, furniture, etc.) and the service sphere (agencies; e.g., real-estate, translation or workforce) (Ben-Rafael et al. 2006:11).

\section{SAMPLE AND METHODOLOGY}

In 2013 we took photos of the linguistics landscape items that can be seen by pedestrians along all busy streets. Then the photos were categorized according to varieties of language use and the meaning, content, and function of the inscriptions. This analysis aimed at revealing who puts up multilingual linguistics landscape items in the multiethnic town, and with what purpose, as well as elucidating the influence of ethnic group's languages on the inscriptions (Hires-László 2015). Following this, in 2017 we took photos of the town's main square and looked for those linguistic landscape items that had changed (statically remained) compared to our 2013 survey. We used social and qualitative analysis with this aim in mind, as well as an assessment of the photos we took at a street fair during a festival in 2017. We tried to assess language use related to the advertising materials and brand names of various products on the basis of local social and economic factors. We aimed to map the street fairs oriented at Ukrainian tourists that are organized in traditionally bilingual (Hungarian and Slavonic: Ukrainian/Russian/Rusyn) settlements. In particular, we were interested in the social and economic processes that influence the linguistic landscape.

The study that was conducted in May 2013 (Hires-László 2015) included only those inscriptions that could be seen in public places by passers-by every day. In other words, it did not include the collection of official correspondence, seals, or prospectuses (Tóth 2016a, 2016b). Furthermore, it did not involve the inscriptions on the buildings of institutions, organizations, or official bodies. In 2013 - immediately after the 2012 law on language was passed - 1178 photos were taken. In the process of analyzing the itinerary, we attempted to choose the busiest town districts for the collection and archiving of more inscriptions (Hires-László 2015). From this perspective, the appearance of the town has been continuously changing, and the process is ongoing. The number of service providers is increasing, mostly in the town's main square. In the period after the change of the regime, some soviet-era service-sector business units almost disappeared (e.g. food, household supplies, clothing shopping 
centers, shoemakers, ice-cream shops, cafés, etc.). Before the economic crisis, these were minimally present in the lives of the town's population. As a result, commerce predominantly occurred in the outdoor marketplace. Nowadays, the situation has changed completely. The pedestrian precinct in the downtown area has an ever increasing number of businesses and service providers. Thus, in the process of study we took the majority of photos in the town's busiest streets including the pedestrian walkways and major adjacent streets. We applied quantitative methods to analyze the pictures collected in 2013 (see the complete material in Hires-László 2015). Jūrate Ruzaitè (2017) also analyzed symbolic expansion (Landry - Bourhis 1997: 25) using the quantitative method that we introduce here (Scollon - Scollon 2003, Backhaus 2006, Ben-Rafael et al. 2006). The former author took 515 digital photos between 2013 and 2014 in three Lithuanian- (Klaipeda, Palanga and Druskininkai) and two Polish cities (Gdynia and Sopot), mainly choosing the central parts of cities that are frequently visited by tourists.

\section{THE LINGUISTIC LANDSCAPE OF BEREHOVE IN 2013 AND 2017}

The essential purpose of our research itinerary (2013) was to map the busiest squares in the town. To ensure coverage of bottom-up inscriptions relating to the whole town, we walked not only along the central, busy pedestrian precinct, but also along other busy streets in the town, including some sidestreets. In the process of analysis we determined what language street-signs we had managed to archive. We classified these according to various criteria depending on whether they were mono- or multilingual ones. Out of all existing language combinations, we drew up a table showing their frequency indices (Table 3). On the whole, we can see that the number of Ukrainian street signs is comparatively high, just like dual Hungarian-Ukrainian ones, but unlike purely Hungarian-language street signs, which are much less common. A situation of parallel multilingualism can be seen in Table 2, while the individual distribution of languages is summarized in Figure 1, which shows that Ukrainian as a state language is much more common in the inscriptions collected in 2013 in public places. 
Table 2 Linguistic distribution of inscriptions on photos taken in 2013 in Berehove as part of the linguistic landscape

\begin{tabular}{|c|c|}
\hline Ukrainian & 514 \\
\hline Hungarian - Ukrainian & 449 \\
\hline Hungarian & 107 \\
\hline Ukrainian - English & 41 \\
\hline Russian & 22 \\
\hline English & 16 \\
\hline Hungarian - Ukrainian - English & 13 \\
\hline Hungarian - Russian & 3 \\
\hline Hungarian - Ukrainian - Latin & 2 \\
\hline Hungarian - English & 2 \\
\hline Hungarian - Ukrainian - Hebrew & 1 \\
\hline Latin & 1 \\
\hline Hungarian - Russian - English & 1 \\
\hline Hungarian - Ukrainian - Russian & 0 \\
\hline
\end{tabular}

(Source: Hires-László 2015)

Figure 1 Language frequency in public places in Berehove according to the 2013 linguistic landscape analysis

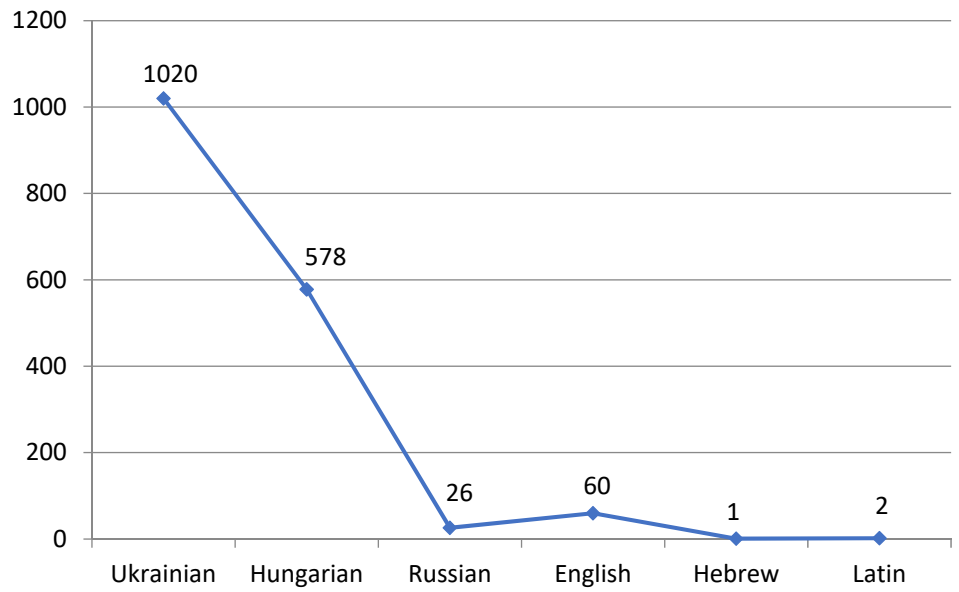


The situation in Berehove is in general as follows: inscriptions of both official and private individuals testify to the fact that the Ukrainian language dominates. However, the multilingualism that is characteristic of the town prevails in street signs in public places (see more in Hires-László 2015). Hungarian and Ukrainian are present in most inscriptions, even though the Hungarian language is less emphasized. Thus, we have determined that in the public places of traditionally multilingual towns there are still multilingual street signs and inscriptions, and this is true of both the official and private sector. The private sector, first of all, adjusts itself to market mechanisms of demand and supply, while official inscriptions depend on the nationalist politics that influence the country's management principles. The settlement mayor's (Zoltán Babják; first period: 2013-2015, second period: 2015-) management principles influence the micro context of the analysis. After the election of the former to the post of town mayor, he tried to report on his activity both in Hungarian and Ukrainian on his Facebook site. Besides this bilingualism, he respects different cultural characteristics - during Christmas holidays celebrated by Hungarians his greeting message can be read first in Hungarian, and then in Ukrainian. The order changes in the greeting card for those who celebrate Orthodox Christmas. The language order and hierarchy are always adjusted to the topical theme and the content of the news that is to be shared. Both dominant ethnic groups (Hungarian and Ukrainian), as well as their language use and symbolic systems, are respected by the mayor in his announcements and signs in symbolic places. His attitude is in full accord with his management principles of strengthening the town as a locality and fostering good, neighborly relations (Appadurai 1996). Moreover, it is emphasized by the reproduction and putting up of valid street signs throughout the town. The present analysis reveals that linguistic landscape research should include presenting the position of the former in social and cultural media as well (Scollon - Scollon 2003). In 2013, street signs were chaotic (see more in Hires-László 2015), while by 2016 the mayor had eliminated this chaos by replacing all the street signs in the town. Side by side with other information, Babják Zoltán posted information about this decision on his public Facebook site, both in Ukrainian and Hungarian. "Last year, those bilingual black-and-white street signs with names of streets and squares were approved. The competent work-group experts approved the Ukrainian and Hungarian names, and in one week from now street-sign production will start. For the attention of corner house-owners: the erection of street signs is planned for April." Replacement started in early February 2016; then in March, the mayor notified people of the continuation of work. In his bilingual report, the mayor explained the replacement of street signs in the following way: "The erection of bilingual street signs in our town with the new names of streets and 
squares is going on. This is why we ask the residents of Berehove, especially the owners of houses at crossroads, to take the replacement of street signs with understanding, and to help with the work. Replacement will take place according to the laws that are in effect. In addition, nameplates will help citizens, tourists, the ambulance service and other service providers to find their way in the town" (date of publication: 31 March, 2016).

Picture 1 New and old style bilingual street signs in Berehove

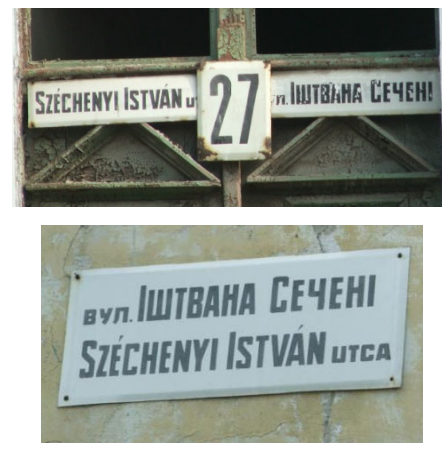

2013

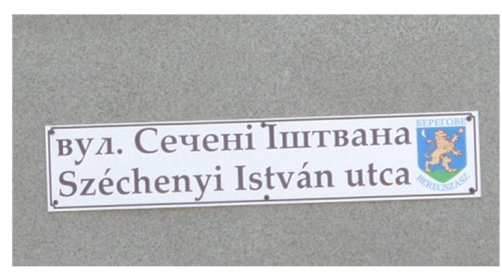

2017

We also analyzed the ethnolinguistic vitality of the languages used in the inscriptions in cases when the interrelation between the languages was characterized by asymmetry or symmetry (Lou 2010, in Laihonen 2012: 28). In the case of asymmetry, minority languages are usually under-represented regarding the style of the inscription (smaller font size, smaller text, lighter shading). The treatment of public inscriptions in visual language use is essentially symmetrical to the number of speakers of the languages of ethnic groups living in the town. However, Ukrainian as the state language enjoys greater emphasis. In the use of the Hungarian language, we often come across grammar mistakes, inscriptions without the correct accents, and even cases when only an abstract or keywords from the Ukrainian text are given in Hungarian. In such cases when the Hungarian language is represented asymmetrically with less emphasis than the Ukrainian language, we considered such street signs to be bilingual and examined the differences in the inscriptions using more detailed analysis (Hires-László 2015). In the analysis of the linguistic landscape of Berehove, ethnic groups are symmetrically represented, except for the Roma and Russians. The language of the Roma community is not present anywhere, although the 
number of Roma in Berehove is substantial. One of the reasons for this is that the majority of the Berehove Roma community consider Hungarian to be their mother tongue.

Furthermore, due to their low social prestige and poverty, their vitality is always secondary in the formation of the town's image. The Russian language plays a much smaller role, even though it is the official language of the Soviet Union (Csernicskó 2013:193-233). We came across Russian inscriptions on street signs that have remained since the change of the regime (Hires-László 2015:174-175). The inscriptions in public places are never in Russian, even though many people in the town use this language in everyday communication. An opinion expressed in a focus group conversation in summer 2016 (Hires-László 2017) reveals that residents of Berehove often use Russian. Although tourists who visit Berehove often use Russian as well, in the case described a tourist demanded the use of the Ukrainian language. In the quote, the informant mentions that in her shop a tourist attempted to correct her with regard to the name of a fruit - asking her to use the Ukrainian equivalent, not the Russian one. The informant had graduated from a Ukrainian-language school and speaks Ukrainian with her husband at home, but she used the Russian equivalent due to everyday routines and customs. Furthermore, this was natural in her immediate environment.

Marianne: This one had no problem with me speaking Hungarian sorry for interrupting you - but he objected to my use of a Russian word; when I said hárbuz, he said kávun [laughs]. Well, he thought it sounded better in Ukrainian because watermelon in Ukrainian is kávun [laughs]. Well, this is it. There were only such things; he corrected me from time to time. The fact that I spoke Hungarian did not disturb him. (Fcs01_2016 May 26)

The prestige of the Russian language in the region has decreased in recent years. TANDEM2016 research reveals the same result: among Hungarian, Ukrainian, Russian, English, and German, the Russian language is considered to have the lowest prestige value (Csernicskó 2017:9). For tourists visiting Berehove, the use of the Hungarian language is natural, but Russian is not, and the Ukrainian-Russian conflict has intensified these negative sentiments. Moreover, the Ukrainian-Hungarian conflict that started in September $2017^{2}$

2 The new law on education that passed in 2017 rendered the lives of minorities in the country more difficult. Ukraine's numerous neighbors, including Hungary, opposed this law. It was followed by the country's political forces waging a media campaign against the Hungarians and Hungary itself, and had numerous negative consequences. For instance, Ukrainian extremist forces held numerous demonstrations in Transcarpathia, and in Berehove in particular. 
may have a similar impact concerning the use of the Hungarian language in Transcarpathia.

\section{ECONOMIC FEATURES REFLECTED IN THE 2017 LINGUISTIC LANDSCAPE}

Another significant area of linguistic landscape analysis, besides the illustration of language policy processes, is when linguistic landscape analyses are used in the assessment of the tendencies characteristic of society. Particular emphasis is given to the study of those economic processes that overlap with social ones. This helps with revealing and perceiving various changes in economic activity. The most significant area of study in this field is tourism and the tendencies within it.

Inscriptions have two essential functions: communicative and symbolic (Landry - Bourhis 1997, in Laihonen 2012: 27). Their communicative character lies in the fact that they transmit information to foreigners, while the symbolic one relates to the population's language distribution as well as the status of languages. On 19-21 May, 2017, Town Day was organized to celebrate the town's $954^{\text {th }}$ anniversary. Since 2001, Berehove has celebrated its nomination to a regional-level town on an annual basis. On Town Day, just like during other events (BeregFest, Wine Festival), there are regular two-three day programs, street fairs, and tents with goods displayed on the main square of the town. Transcarpathia - including Berehove - has become a destination point for many tourists. Formerly they came from Hungary; now they arrive from other regions of Ukraine (mainly from Kyiv and its precincts) (Csernicskó - Laihonen 2016; Karmacsi 2017).

Tourists are attracted by the area's variegated scenery and multiethnicity. More and more local people are interested in tourism at different levels. Accordingly, it has become a significant branch of the economy in the region, and this can be perceived in service areas and commercial units and their products. In 2014, the outbreak of the war in eastern Ukraine caused a new wave of permanent and cyclic migration of the population. To support the Hungarian population to stay in the region, the current Hungarian government elaborated the Egán Ede plan, ${ }^{3}$ which highlighted the development of tourism as a high priority branch of the economy. This led to various investment and development schemes in the area. Various impact assessment studies have dealt with the development of tourism that is giving the area a powerful economic boost (Berghauer 2012, Tarpai 2013).

3 https://www.eganede.com/egan-ede-terv.pdf

CORVINUS JOURNAL OF SOCIOLOGY AND SOCIAL POLICY VOL. 10 (2019) 1 
Over the last two-three years (right after Ukraine lost the Crimean peninsula), the number of tourists visiting the area has increased. The local population of the peninsula decided on discretional annexation. As a result, tourists travelling within country borders chose to visit Transcarpathia for its beautiful exotic scenery instead of Crimea. The number of tourists may change significantly, taking into account the fact that since the summer of 2017 Ukrainian tourists have been able to travel visa-free to any European Union member state provided they have a biometric passport.

The wine producers participating in the Town Day are not traditional winegrowers, for their goods include various kinds of home-made alcohol. Wine production in Berehove has a history. Viticulture started and became established as early as the $13^{\text {th }}$ century by the Saxons at the time of King Béla (Lehoczky [1881] 1999:29), while the Counts of Shönborn at the time of their tenure set up state-of-the-art viticulture in the area (Lehoczky 1999). In the course of the collectivization of farms in the Soviet Union, viticulture was transformed into mass production. At the time of the change of the regime, due to economic decline and a lack of capital this tradition fell out of favor and disappeared from the palette of economic activities. One of the reasons for this was the lack of competence and professional skills. Resuscitation of the industry started in the 2000s with some wine producers on several farms and vineyards who possessed the diligence to become engrossed in the craft of viticulture and vinification. Currently, the largest target audience of wine producers includes tourists from Ukraine's other regions, while formerly tourists from Hungary often visited this region. Thus, the region's wine producers and those willing to become winegrowers build on viticultural and winegrowing cultural traditions to master this craft gradually. The inscriptions and informative brochures of the wine producers participating in the exhibition were mainly in Slavic languages, and the vendors in the stalls mainly used Ukrainian/Russian/Rusyn (Ruthenian) languages. When it comes to small producers, it is generally relatives, family members, or producers themselves who offer their wares. The majority of wine producers came from the Mukachevo district, not Berehove district, which would seem more logical. This phenomenon can be explained by the fact that the majority of tourists are able to visit these wine-making areas. Moreover, wine tasting for those who were interested was predominantly organized by the wine producers in their wine cellars. However, there is another tendency among wine producers. Those Hungarian-speaking wine producers who formerly served tourists from Hungary now attract and serve Ukrainian tourists and predominantly use the Ukrainian language on labels for their merchandise and in the production of other souvenirs. For instance, to promote their wineries wine producers have fridge magnets produced in Ukrainian/Russian. We found 
just one Hungarian inscription on a wine producer's tent. He came from Dercen, a predominantly Hungarian village in Mukachevo district. This was also the case with the Hungarian inscriptions on the stall's main poster that looked incidental next to the Ukrainian ones, and other inscriptions were not translated into Hungarian. A typical example of asymmetry: although the inscriptions were bilingual, the emphasis and priority were given to the language that best serves economic interests; in this case, the state language.

Adjusting to the demands of Slavic tourists, some wine producers make different varieties of home-distilled vodka and cognac. In any case, alcoholic beverages on sale in the street fair were labeled in Ukrainian and Rusyn. The Berehove Cotnar wine-making company also presented its goods on the main square of Berehove with Ukrainian labels only. The company name is a historical name that can first of all be connected with the Hungarian ethnos. ${ }^{4}$ The VIP Bar company name is English. Presumably by using a world language they seek to follow a middle path and attract both Ukrainian and Hungarian consumers. English company names are successfully used in Transcarpathia (Hires-László 2015, Csernicskó 2017), and by using a world language such names become understandable to everybody (Ukrainian, Hungarian, and other nationality tourists). The VIP Bar on the main square chose this solution as well, and used not the English language, but Ukrainian and Hungarian. The seller was Hungarian-speaking. However, he had a detailed list of cocktails, coffee and alcoholic beverages in Ukrainian. This was the only stall with bilingual inscriptions where Hungarian dominated. However, it was not incidental that this stall did not attract many tourists. In a stall selling jams and decorations the company name, labels, and prospectuses were also in English. The English language was used in company names and on some labels. There were even cases when 'hot-dog' was transliterated into Ukrainian using Cyrillic letters.

English language use covered the inscriptions' informative character. However, the symbolic meanings were lost. It would have enriched the goods' ethnocultural character if the languages of the two dominant ethnic groups (Ukrainian/Rusyn-Hungarian) were used side by side (Piller 2003:175). English company, brand and product names were based on the region's characteristic features and their use could have been motivated by rational consideration (Ben-Rafael et al. 2006:7). Rational consideration, in this case, means that the use of English-language brand names was more pronounced in relation to the sale of products than the language used by the local population. The use of the

4 The word 'Cotnar' can be etymologically traced back to the Romanian settlement Cotnari. According to settlement legends, at the time of King Matthias Corvinus's wedding a grapevine was planted in the settlement, which is now famous for its delicious dessert wine. 
English language aims at increasing products' prestige value (Ben-Rafael et al. 2006: 16). English language could not be found anywhere else at the street fair, except on labels and in brand names. Although this event specializes in tourist merchandise, one rarely sees inscriptions in any other language than Ukrainian. Alongside wine production, there are two other essential goods at Transcarpathian markets and fairs. Honey (together with its by-products) and cheese-making dominate the Transcarpathian economy. The latter includes, first of all, various kinds of goat cheese seasoned with fresh herbs and other vegetables. Transcarpathian producers make specific goods and sell them at street fairs. These include jam, wooden and fur-based instruments, goods with Ukrainian national motifs (vyshyvanky: Ukrainian traditional clothing which contains elements of Ukrainian ethnic embroidery, and rushnyky: a fabric used in rituals embroidered with symbols and cryptograms of the ancient world), different kinds of meat products (sausages, bacon and ham), jewelry made of precious stones, medicinal herbal tea, and essential oils. The stalls selling merchandise mentioned above were characterized by Ukrainian language use: there was not a single Hungarian-language inscription (Picture 2). Goat cheese is typically sold to tourists at street fairs organized in the busiest places. The thermal water pool built during the time of the Soviet Union is also now mostly visited by tourists. Due to the medicinal effects of the thermal water, tourists visit the town's pool in high season in large numbers. The settlement also has a much higher level bathhouse built on the same thermal spring. Side by side with the pool there has been a smaller stationary street fair in recent years. In the summer of 2017, labels on goat cheese were bilingual (Rusyn/Hungarian) (Picture 3), while the vendors speak only Ukrainian/Russian. However, abiding by local customs, and even though they serve mainly Ukrainian tourists, the goods are labeled in Hungarian as well. Thus, at the local level in a bilingual town, an ethnocultural emphasis is essential for producers, especially if they are selling Transcarpathian gastronomical specialties. 
Picture 2 Monolingual inscription on goat cheese sold at a street fair on Berehove Town Day (May 2017)5



Picture 3 Bilingual inscription on goat cheese sold near a thermal water pool that is visited by tourists (August 2017)

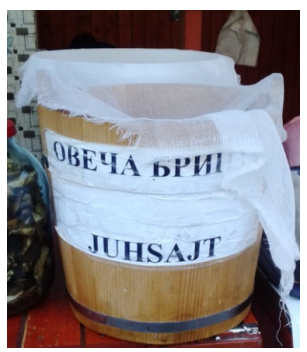

Several candy floss vendors offered their goods on Town Day; however, Hungarian-language linguistic landscape items could only be seen in one place (Picture 4). Alongside candy floss, one could buy popcorn, ice creams, hot-dogs and potato chips. English names dominate the latter two products, but other goods had only Ukrainian labels. In general, the language use of the whole street fair was predominantly Ukrainian.

Picture 4 Candy floss vendor with Hungarian and Ukrainian inscriptions

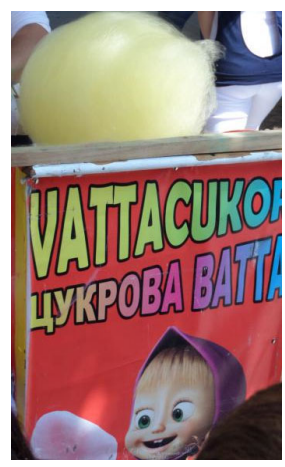

Rovas encoding (an old Hungarian script) can be found first of all on some Transcarpathian settlements' nameplates (Karmacsi 2014a, 2014b) but it is less often used for the names of goods and services. Despite the dominant Ukrainian Town Day medium, Szekler script could also be found in the promotional

5 The photos used in the research were taken by the author. 
poster for Transcarpathian langos (fried dough) side by side with Ukrainian and Hungarian inscriptions. To emphasize Hungarian products, national colors were used in the linguistic landscape items. Moreover, the female vendor wore an embroidered dress with Hungarian motifs. We also documented one more specific case of sales with an ethnocultural characteristic - a vendor wore clothes with national motifs, used a particular script, and offered for sale ethnic gastronomy goods with bilingual inscriptions.

\section{SYMBOLIC SYSTEMS OF ETHNIC GROUPS AS ITEMS OF THE LINGUISTIC LANDSCAPE}

The use of the symbolic system of various ethnic groups becomes the object of analysis in the linguistic landscape. The same tendencies characterize the use of national symbols in Berehove as with language use - the symbols of the two dominant ethnic groups can be found at the entrance to and on the interior walls of the institutions and organizations that function in the town. The use of the system of symbols of minorities in Ukraine is regulated by the law on national minorities in Ukraine adopted on 24 June 1992. Moreover, it is governed by the edict that was enforced by the Hungarian faction functioning in the Transcarpathian Regional Council on 17 December, 1992. These determine the minorities' (mainly Hungarians') system of symbols in the region (Tóth Csernicskó 2009:82). Now, language use is regulated by the 2012 language law (Csernicskó 2016). The system of symbols of both dominant ethnic groups in Berehove is constantly present both in official (top-down) and privately set up (bottom-up) places (Ben-Rafael et al. 2006).

The use of colors to represent national symbols, together with inscriptions in different languages, mark the square and make perceptible the presence of the nationalities living on this territory. There are numerous opportunities to elucidate the unique character of ethnic groups. Hobsbawm (1990) claims that the national state tries to make its ideology clear by means of imparting to the square symbolic meanings that have their roots in nationalism. For that very reason, Arjun Appadurai (1996) emphasizes the fact that in the wars these ideologies wage, locality can be and is of vital importance. Locality is not necessarily a spatial notion; it is a characteristic feature of social life "formed through the sense of social immediacy, interaction technology, as well as by the relations between the contexts that have become relative." The author claims that top-down nationalist ideologies make it hardly possible to create a neighborhood. He interprets the neighborhood as the current social form in which locality is manifested as a dimension or value (Appadurai 1996). Tim 
Edensor (2002) claims that the present forms of nationalism should be searched for in popular culture, singling out three critical aspects of the former: (1) nationalism by means of the spatialization of nationhood and ideologically and mythologically significant landscapes and iconic locations; (2) nationalism by virtue of the performative realization of nationhood, including through sports events, carnivals and tourism; as well as, (3) nationalism through learning what a "national consumer" is; i.e., by attracting attention to phenomena such as national car brands.

Anthony D. Smith (1995) differentiates four meanings of the word "nationalism":

(1) the general process of forming a nation that is sometimes called formation of a nation (however, the phrase often includes the processes of state formation);

(2) a national idea or feeling, attitude or awareness of belonging to a nation, aspirations for its welfare, strength and safety;

(3) achieving or maintaining a national status (with all its concomitants) as the political aim of a movement, including the organization and the activity required to achieve it;

(4) science, or in the broader sense ideology, that deals with the nation and aims to create its autonomy, unity and a sense of identity.

Even though this notion is strongly polysemantic, in everyday life its negative connotations are most common (Michnik 1992); at events and in day-to-day life we see representations of these symbolic systems with a perceptible locality. Nationalism becomes part of everyday life in the sense that when symbols are used to strengthen and support the national idea, locality is being formed. Therefore, the use of the tricolors of ethnic groups living side by side peacefully for many decades is not meant to strengthen a nationalist movement, but rather to build upon locality (Appadurai 1996).

Further on, through performative realization, we focus on an analysis of tourism whereby economic determination is of high importance. In the study of linguistic landscapes, one can evaluate the analysis of nationalist ideologies (Hobsbawm 1997, Smith 1995, Michnik 1992), localities/neighborhoods (Appadurai 1996), and economic mechanisms, whereby we investigate the essence of "putting up for sale" ethnic and cultural characteristics. The latter analysis is undertaken by searching for the motivation behind the inscriptions, as well as their characteristics, via surveying the linguistic landscape. For example, a message on the town's dominant building is nationalist in character. However, it is used to represent multiethnicity and the emphasis lays in communicating harmonious neighborly relations to town residents and visitors alike. 
Picture 5 The main square in the colors of the national flags of Ukraine and Hungary (blue-yellow, red-white-green, respectively) on Town Day 2016 and 2017


Thus, both in language use and in the use of symbols one can distinguish two ethnic groups in Berehove. In the use of symbolic systems, first of all, emphasis on a neighborhood and harmonious living side by side is the centre of attention, playing down extremist nationalist ideologies: i.e., a culturespecific order approved by the state functions in the town (Ilyés 2010:116). In a multiethnic community without extremist nationalist forces, multilingualism becomes natural and routine. As a result, symbolic systems of various ethnic groups coexist alongside each other. Nationalism emerging in a multiethnic community due to the long-term coexistence of such groups may develop owing to transactionalism (Conversi 1998). The essence of transactionalism lies in those exchanges and interrelations between ethnic groups that loosen the borders between the groups (Barth 1969, 1996), thereby making border crossing much easier, unlike the nationalist ideologies that build up borders between ethnic groups.

Picture 6 The fixed symbolic system of Berehove programs - use of the Hungarian and Ukrainian national colors (on the left of the gate, red, white and green balloons, and on the right blue and yellow balloons)

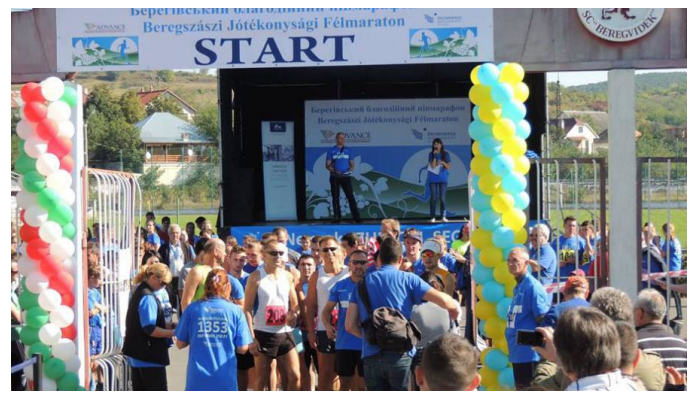


We interpret the linguistic landscape used in tourism as the popular culture in which localities and nationalist ideologies emerge (not according to the pejorative meaning of the latter word [Smith 1995]).

Ukrainian nationality- and Ukrainian-speaking people prevail in Lviv. Moreover, it is often a centre of extremist nationalist views. Among the restaurants found at the fair there was a Lviv Cossack restaurant as well, although it was surprising that only (traditionally Hungarian) goulash soup could be ordered there, while Cossack soup was not on the menu. The name and food offerings of the stall built on Ukrainian national ideology and showed that although nationalist ideology is present, it is founded on economic interest and adjusts itself to the area's multiethnicity in relation to the sale of Hungarian cuisine to Ukrainian tourists. There were no Hungarian-language inscriptions anywhere. On the other hand, there was a stall that communicated to passers-by by means of symbols and language that Ukrainian and Hungarian ethnic groups get on well with one another. This example completes our analysis. It clearly shows that in the stalls of local entrepreneurs, friendliness is of particular importance. Symbols emphasize local identity in a popular culture where, through ethnic and cultural characteristics, the goal is to sell goods and make economic profit.

\section{SUMMARY}

In 2013 and 2017 we carried out a linguistic landscape study with two similar methods in the western Ukrainian town of Berehove. In 2013, we followed a process of collecting statistical data about the languages used in inscriptions in public places. In 2017 we followed the same itinerary, but besides collecting statistical data we also undertook photo documentation, thereby revealing the changes in the linguistic landscape of the town's public places compared to the 2013 study. The social and political tendencies experienced in the country (Fedinec - Halász - Tóth 2016, Fedinec - Csernicskó 2017a, 2017b) significantly influence everyday life, and, consequently, the linguistic landscape as well. The decisive political event in the period between 2013 and 2017 was the intensification of the conflict between Ukraine and Russia due to Russia's support for the separatist territories in eastern Ukraine. Thus, our analysis includes a description of the consequences of both political and military battles. Our analysis reveals that bilingualism is still evident in most places in Berehove, and the mayor's management principles strengthen this tendency.

We studied the linguistic landscape not only from the point of view of language laws, but our analysis included social and economic processes as well. To illustrate the changes in economic processes, we analyzed some modifications 
in inscriptions and company names that helped in assessing the transformation of economic processes in the area. We tried to elucidate what dynamic changes the linguistic landscape can produce which intensify those shifts that we experience both in economic processes and in politics and society that influence language use. Csernicskó István (2016) drew similar conclusions. He studied the interrelation between the linguistic landscape and language policies over a much longer time interval (1918 to the present day), concluding: "In the process of language policy researches [sic] the analysis of linguistic landscape in its broader sense can offer useful information not only [for] revealing the hierarchical relations of some languages but also [for] achieving and changing language dominance" (Csernicskó 2016:60).

We have come to the conclusion in the process of analyzing the linguistic landscape of the Town Day that Ukrainian-language inscriptions were predominant visible on goods sold at the street fair in the main square of Berehove. Inasmuch as mainly Ukrainian tourists visit this area, the inscriptions are, first of all, oriented at them, which is the reason why they were mostly in Ukrainian. In Berehove, two ethnic groups dominate in terms of the use of symbols and language. However, the street fair organized on Town Day shows a different picture. There are rare cases of Hungarian-language use, but these are not as dominant as they are in general in the town. The buyers' language use is the dominant factor in relation to inscriptions on goods that represent cultural traditions, and the majority of sales units in the area use the Ukrainian language. Product labels for tourists are adjusted to economic principles of supply and demand. An emphasis on ethnic and cultural character is prioritized to generate more profit. As a result, the bilingual traditions of the region are not displayed in the inscriptions used at the street fair organized on Town Day.

\section{REFERENCES}

Appadurai, Arjun (1996), Modernity at Large: Cultural Dimension of Globalization. Minneapolis, University of Minnesota Press.

Backhaus, Peter (2006), "Multilingualism in Tokyo: A Look into the Linguistic Landscape." International Journal of Multilingualism Vol. 3, No 1, pp. 52-66. https://doi.org/10.1080/14790710608668385

Barni, Monica - Bagna, Carla (2015), "The critical turn in LL. New methodologies and new items in LL". Linguistic Landscape Vol. 1, No 1/2, pp. 6-18., DOI: 10.1075/11.1.1/2.01bar

Barth, Frederik (ed.) (1969), Ethnic groups and boundaries: The social organization of cultural difference. Boston, Little Brown. 
Barth, Frederik (1996), Old and new problems in ethnicity analysis [Régi és új problémák az etnicitás elemzésében]. Regio Vol. 7, No 1, pp. 3-25.

Ben-Rafael, E. - Shohamy, E. - Amara, M. - Hecht, N. (2006), "The symbolic construction of the public space: The case of Israel". International Journal of Multilingualism, Vol. 3, No 1, pp. 7-28. DOI: 10.1080/14790710608668383

Ben-Rafael, Elizier et al. (2010), "Introduction”. In Shohamy, Elena et al. (eds.) Linguistic Landscape int he City. Bristol, Multilingual Matters, pp. xi-xxviii. DOI: 10.1075/11.1.1-2.001int

Berghauer, Sándor (2012), A turizmus mint kitörési pont Kárpátalján (?) Értékek, remények, lehetöségek Ukrajna legnyugatibb megyéjében). [Tourism is the breakthrough point in Transcarpathia (?) Values, hopes, opportunities in the westernmost province of Ukraine] dissertation. University of Pécs, Doctoral School of Earth Sciences. Available: http://old.foldrajz.ttk.pte.hu/ phd/phdkoord/nv/disszert/disszertacio_berghauer_nv.pdf

Conversi, Daniele (1998), "A nacionalizmuselmélet három irányzata" [The three trends of nationalism theory.] Regio Vol. 9, No. 3, pp. 37-55.

Csernicskó, István (2013), States, Languages, State Languages. Language policy in today's Transcarpathian region (1867-2010). [Államok, nyelvek, államnyelvek. Nyelvpolitika a mai Kárpátalja területén (1867-2010)] Budapest, Gondolat Kiadó.

Csernicskó, István (2016), Language policy in the war in Ukraine [Nyelvpolitika a háborús Ukrajnában]. Ungvár, Autdor-Shark.

Csernicskó, István (2017), Language, education and language usage in the light of an empirical research [Nyelv, oktatás és nyelvhasználat összefüggéseiröl egy empirikus kutatás adatainak tükrében]. Közoktatás 2017. No. 2-3., pp. $6-10$

Csernicskó, István - Laihonen, Petteri (2016), Hybrid practices meet nationstate language policies: Transcarpathia in the twentieth century and today. Multilingua-Journal of Cross-Cultural and Interlanguage Communication. Vol. 35, N. 1, pp. 1-30. DOI: https://doi.org/10.1515/multi-2014-0073

Csernicskó, István - Máté, Réka (2017), Bilingualism in Ukraine: Value or Challenge? Sustainable Multilingualism No. 10, pp. 14-35. DOI: http://dx.doi. org/10.1515/sm-2017-0001

Csernicskó, István - Orosz, Ildikó (1999), The Hungarians in Transcarpathia. Budapest, Tinta Könyvkiadó.

Edensor, Tim (2002), National Identity, Popular Culture and Everyday Life. Oxford-New York: Berg. www.lse.ac.uk/internationalRelations/.../Fox\%20 Miller-Indriss.pdf

Fedinec Csilla - Csernicskó István (2017a), (Re)conceptualization of Memory in Ukraine after the Revolution of Dignity. Central European Papers Vol. 5, 
No. 1, pp. 46-71. http://www.slu.cz/fvp/cz/web-cep/archiv-casopisu/2017-vol5-no.1/csilla_fedinec_reconceptualization

Fedinec, Csilla - Csernicskó, István (2017b), Language Policy and National Feeling in Context Ukraine's Euromaidan, 2014-2016. Central European Papers Vol. 5, No. 1, pp. 81-100. http://real.mtak.hu/72640/1/fedinec csernicsko_language_policy_u.pdf

Fedinec, Csilla - Vehes, Mikola (2010), Transcarpathia 1919-2009 (History, politics, culture).[ Kárpátalja 1919 -2009 (történelem, politika, kultúra)] Budapest, Argumentum, MTA Ethnic-National Minority Research Institute Fedinec, Csilla - Halász, Iván - Tóth, Mihály (2016) Independent Ukraine: State Building, Constitution and Submerged Treasures [A független Ukrajna: Államépités, alkotmányozás és elsüllyesztett kincsek]. Pesti Kalligram, Budapest.

Hires-László, Kornélia (2015). Linguistic landscapes and ethnicity in Beregszász [Nyelvi tájkép és etnicitás Beregszászon]. In: Márku, Anita - Hires-László, Kornélia ed. Language teaching, bilingualism, language landscape. Studies from the Linguistics Research Center of Antal Hodinka I. [Nyelvoktatás, kétnyelvüség, nyelvi tájkép. Tanulmányok a Hodinka Antal Nyelvészeti Kutatóközpont kutatásaiból] Uzhgorod, Autdor-Shark, pp. 160-185.

Hires-László, Kornélia (2017), Ethnic categories in the everyday discourses of the Beregasians [Etnikai kategóriák a beregszásziak mindennapi diskurzusaiban]. In: Márku, Anita - Tóth, Enikő ed. Multilingualism, regionalism, language teaching. Studies from the Linguistics Research Center of Antal Hodinka III. [Többnyelvüség, regionalitás, nyelvoktatás. Tanulmányok a Hodinka Antal Nyelvészeti Kutatóközpont kutatásaiból III.] Uzhgorod, „RIK-U”, pp. 121136.

Hires-László, Kornélia (2018a), Linguistic landscape and tourism in Beregszász. Language Landscape, Language Diversity Workshop Publishing. Manuscript submitted for publication.

Hires-László, Kornélia (2018b), Nyelvi tájkép változása Beregszászon [Change of linguistic landscape in Beregszász]. In Karmacsi, Zoltán - Máté, Réka ed. Nyelvek és nyelvvátozatok térben és időben Tanulmányok a Hodinka Antal Nyelvészeti Kutatóközpont kutatásaiból IV. [Languages and language versions in space and time. Studies from the Linguistics Research Center of Antal Hodinka IV]. Uzhgorod, "RIK-U”, pp. 183-196.

Hobsbawm, Eric J. (1990) Nations and nationalism since 1780. Cambridge; New York: Cambridge University Press

Ilyés, Zoltán (2010), Ethnicity and Symbolic Geography. Expropriating the landscape, especially in border areas and contact zones [Etnicitás és szimbolikus geográfia. A táj kisajátítása, különösen határvidékek, 
kontaktzónák esetén]. In Margit, Feischmidt ed. Ethnicity. Differentiating society [Etnicitás. Különbségteremtő társadalom]. Budapest, Gondolat-MTA Institute for Minority Research.

Ruzaité, Jūratė (2017), The linguistic landscape of tourism: multilingual signs in Lithuanian and Polish resorts. ESUKA - JEFUL Vol. 8, No. 1, pp. 197-220. DOI: https://doi.org/10.12697/jeful.2017.8.1.11

Karmacsi, Zoltán (2014a), Towns and street names in Transcarpathian in Hungary settlements [Település és utcanevek Kárpátalja magyarlakta településein]. In Beregszászi, Anikó - Hires-László, Kornélia ed. "Beside the lined walls". Birthday greetings for István, Kótyuk. [Meszelt falakon túl. Születésnapi köszöntökötet Kótyuk István tiszteletére] Beregszász, Antal Hodinka Insitute, pp. 87-98.

Karmacsi, Zoltán (2014b), Visual bilingualism: the possibilities offered by the new language law [Vizuális kétnyelvüség: az új nyelvtörvény adta lehetőségek] In: Bárány, Erzsébet - Csernicskó, István ed. The past and present of the Ukrainian-Hungarian language relations. Presentations of the International Scientific Conference [Az ukrán-magyar nyelvi kapcsolatok múltja és jelene. Nemzetközi tudományos konferencia elöadásai]. Ungvár, "V. Pagyak", pp. $120-132$.

Karmacsi, Zoltán (2017), One aspect of the change in linguistic landscape [A nyelvi tájkép változásának egy aspektusa]. In: Márku, Anita - Tóth, Enikő szerk. Multilingualism, regionalism, language teaching. Studies from the Linguistics Research Center of Antal Hodinka III. [Többnyelvüség, regionalitás, nyelvoktatás. Tanulmányok a Hodinka Antal Nyelvészeti Kutatóközpont kutatásaiból III.] Ungvár, “RIK-U”. pp. 54-60.

Lehoczky, Tivadar (1999, [1881]), Additives for Beregszász history [Adalékok Beregszász történethez]. Ungvár, Kárpátaljai Magyar Kulturális Szövetség.

Laihonen, Petteri (2012), Linguistic landscape in a Csalóköz and a Mátyusföld village [Nyelvi tájkép egy csallóközi és egy mátyusföldi faluban]. Fórum Társadalomtudományi Szemle [Forum Social Science Review] Vol. 14. No 3, pp. 27-49.

Landry, Rodrigue - Bouris, Richard (1997), Linguistic landscape and ethnolinguistic vitality. Journal of Language and Social Psychology, Vol. 16. No 1, pp. 23-49. DOI: https://doi.org/10.1177/0261927X970161002

Michnik, Adam (1992), Limits of a concept. [Egy fogalom határai.] Világosság, Vol 32, No 5., pp. 328-331.

Piller, Ingrid (2003), Advertising as a Site of Language Contact. Annual Review of Applied Linguistics Vol. 23, pp. 170-183. DOI: 10.1017/S0267190503000254 Scollon, Ron - Scollon, Suzie Wong (2003), Discourses in place. Language is the Material World. London, Routledge. 
Shohamy, Elana - Ben-Rafael, Eliezer (2015), Introduction, Linguistic Landscape Vol. 1, No 1, pp. 1-5. DOI 10.1075/11.1.1.001int

Shohamy, Elana - Waksman, Snoshi (2009), Linguistic landscape as an ecological arena: Modalities, meanings, negotiations, education. In: Elana Shohamy \& Durk Gorter (eds.) Linguistic landscape: Expanding the scenery. New York-London: Routledge, pp. 131-331.

Shohamy, Elena (2006), Language policy: Hidden agendas and new approaches. London: Routledge.

Shohamy, Elena (2015), LL research as expanding language and language policy. Linguistic Landscape Vol 1, No1 152-171. DOI 10.1075/11.1.1/2.09sho. Smith, Anthony D. (1995), Nationalism [A nacionalizmus]. In: Bretter, Zoltán - Deák, Ágnes ed. Ideas in politics: nationalism [Eszmék a politikában: a nacionalizmus], Pécs, Tanulmány Kiadó, pp. 9-24.

Tarpai, József (2013), The role of natural and social resources in Transcarpathia tourism development and its impact a regional development [A természeti és társadalmi erőforrások szerepe Kárpátalja turizmusfejlesztésében és hatása a területfejlesztésre]. PhD dissertation. University of Pécs,

Tóth, Mihály - Csernicskó, István (2009), The development of minority legislation in Ukraine and its two sub-areas: the use of names and political representation [Az ukrajnai kisebbségi jogalkotás fejlődése és két részterülete: a névhasználat és a politikai képviselet.] Regio Vol. 20, No 2, pp. 69-107.

Tóth, Enikö (2016a), Languages in virtual space: the use of the official websites of Subcarpathian Hungarian settlements [Nyelvek a virtuális térben: kárpátaljai magyarlakta települések hivatalos honlapjainak nyelvhasználata]. In: Gazdag, Vilmos - Karmacsi, Zoltán - Tóth, Enikő ed. Values and Challenges Volume I: Linguistics [Értékek és kihívások I. kötet: Nyelvtudomány]. Ungvár, AutdorShark. pp. 230-238.

Tóth, Enikő (2016b), Internet communication of administrative units in Beregszász district [A Beregszászi járás közigazgatási egységeinek internetes kommunikációja]. In: Hires-László, Kornélia ed. Language use, bilingualism. Studies from the Linguistics Research Center of Antal Hodinka II [Nyelvhasználat, kétnyelvüség: Tanulmányok a Hodinka Antal Nyelvészeti Kutatóközpont kutatásaiból II.], Ungvár: Autdor-Shark, 2016. pp. 163-170. 
